\title{
Openness in Scandinavian Classrooms: Student Perceptions of Teaching Practices and High Achievers of Civic Knowledge
}

\author{
Lihong Huang ${ }^{*}$, Heidi Biseth ${ }^{2}$ \\ ${ }^{1}$ NOVA-Norwegian Social Research, Oslo and Akershus University College of Applied Sciences, Oslo, Norway \\ ${ }^{2}$ Department of Human Rights, Religion and Social Sciences, University College of Southeast-Norway, Drammen, \\ Norway \\ Email: "lihong.huang@nova.hioa.no, heidi.biseth@hbv.no
}

Received 7 January 2016; accepted 26 April 2016; published 29 April 2016

Copyright (C) 2016 by authors and Scientific Research Publishing Inc.

This work is licensed under the Creative Commons Attribution International License (CC BY).

http://creativecommons.org/licenses/by/4.0/

(c) (1) Open Access

\begin{abstract}
In this paper, we explore how teaching practices in classrooms influence students' civic knowledge achievement in three Scandinavian countries: Denmark, Norway, and Sweden. Using data from the 2009 International Civic and Citizenship Education Study (ICCS), our investigation focuses on the measures of "open classroom climate", which include seven items that ask students how often they experience each of the seven teaching practices during regular lessons. From the students' perspective of teaching practices in the classroom, we hypothesize and assume that there should be a balanced combination of classroom practices where each method/activity carries a different weight or level of importance. Applying logistic regression analysis, we assess the effect of each of the practices on the probability with which a student becomes a high achiever of civic knowledge (as represented by odds ratios). Our results show both similarities and differences in the combinations of classroom practices that have contributed to students' high civic knowledge achievement in the three Scandinavian countries. Our findings provide useful messages to teachers in the classroom, and they also have implications for teacher education and research.
\end{abstract}

\section{Keywords}

Openness in the Classroom, ICCS 2009, Civic Knowledge Achievement, Teaching Practices, Student Perception

\section{Introduction}

Besides being geographically located on the same peninsula with rather similar political and social welfare sys"Corresponding author.

How to cite this paper: Huang, L., \& Biseth, H. (2016). Openness in Scandinavian Classrooms: Student Perceptions of Teaching Practices and High Achievers of Civic Knowledge. Creative Education, 7, 713-723. 
tems, the three Scandinavian countries (Denmark, Norway and Sweden) also share some common cultural and historical characteristics, including a common language root. The three countries all have an education system featuring free public schools that provide compulsory schooling to all children from the ages of 6 or 7 years to the age of 16 years. As established democratic societies, Scandinavian countries have historically used the schooling system as a tool to strengthen democracy by preparing the young for their future roles as citizens (Biesta, 2006; Biseth, 2009, 2012; Jacobsen et al., 2004). Table 1 presents the statistics featuring the education sector in the three countries. With some small variations between the countries, the three countries stand out from the Organisation for Economic Cooperation and Development (OECD) average in terms of both investment in education, as indicated by the percentage of gross domestic product (GDP) spent on education, and achievement in education, which is indicated by the percentages of the population of aged 25 years and older with education attainment at, or beyond, the secondary school level.

In all three countries, civic and citizenship education as apriority is stated rather implicitly, rather than explicitly, in educational policies (Biseth, 2009). There are only minor variations in the implementation of civic and citizenship education across the three countries, as educational institutions approach these areas by integrating these topics into several study subjects in school and emphasising student participation (Bruun, 2013; Lind, 2013; Mikkelsen \& Fjeldstad, 2013; Schulz et al., 2010). Scandinavian students are regarded as “above average” achievers by international comparisons, as reported in the 2009 International Civic and Citizenship Education Study (ICCS 2009). In comparison with an average of $28 \%$ students reached Level 3 proficiency in civic knowledge among the 36 participant countries reported by the ICCS 2009, over half (58\%) of Danish students, $32 \%$ of Norwegian students, and $40 \%$ of Swedish students did so (Schulz et al., 2010).

Previous research on the factors that contribute to individual achievement in civic knowledge, civic attitudes, civic behaviours, and civic engagement has repeatedly demonstrated the significant influence of one's home (Levinson, 2010). First, parents' socio-economic status is significantly and positively associated with young people's civic knowledge and behavioural development in the cases of the United States (Zaff et al., 2009) and elsewhere around the world (Schulz et al., 2010). Parental interest in political and social issues, as well as their discussion of these issues with their children at home, not only significantly influences young people's civic knowledge achievement (Schulz et al., 2010), but also contributes to the development of children's interests in these issues, leading to their eventual civic engagement (Lauglo \& Øia, 2006; McIntosh et al., 2007; Richardson, 2003; Seider, 2012). Moreover, research finds that parents’ own civic engagement also has a positive association with children’s social, civic, and political participations (Cicognani et al., 2012).

However, when it comes to the influence of schools and classrooms in student civic knowledge achievement, civic attitudes, and behaviour, the research evidence is often limited and sometimes presents mixed messages. For example, an "open classroom climate" as an "individual learning context" is found to have a significant positive effect on a student's achievement of civic knowledge in many countries. At the same time, when analysing an "open classroom climate” as an aggregate of "school learning context”, it does not have significant effect on student achievement at school level in many countries in the ICCS 2009 study (Schulz et al., 2010; Mikkelsen et al., 2011; Lieberkind, 2015). Barber et al. (2015) have pointed out that if students in a classroom have different perceptions of their classrooms, their aggregate perception about the classroom would be less reliable than the perceptions held by students in a classroom with a strong level of agreement. This complicates how the results of the ICCS can be of use in teachers' practice.

Table 1. Indicators of education among the three Scandinavian countries in comparison with the OECD average.

\begin{tabular}{|c|c|c|c|c|}
\hline & Denmark & Norway & Sweden & OECD average \\
\hline Investment in education as \% of GDP & 8.8 & 8.8 & 7.0 & 5.8 \\
\hline $\begin{array}{l}\text { Population (ages } 25 \text { - } 34 \text { years) with at least upper secondary education } \\
\text { attainment in \% }\end{array}$ & 81.75 & 82.07 & 90.79 & 82.47 \\
\hline Population (ages 25 - 64 years) with tertiary education attainment in \% & 34 & 38 & 35 & 32 \\
\hline Years of compulsory schooling & 10 & 10 & 9 & 9 \\
\hline Ratio of students to teaching staff in secondary education & -- & 10 & 12 & 14 \\
\hline
\end{tabular}

Data source: OECD (2013, 2015). 
With the aim of contributing to teaching practices in the classroom, we ask a specific research question: to what extent does each of the teaching practices in the classroom contribute to increased students' civic knowledge achievement in the three Scandinavian countries? Our investigation takes an approach which differs from that of previous studies on the relationship between an open classroom climate and civic knowledge achievement among students. Instead of following the previous assumption that a linear and positive relationship between an open classroom climate and student achievement exists, we propose a consideration whereby the positive relationships between the classroom practices and student achievement are not all straight and linear. Our intended message to teachers in practice would be that there is a positive relationship between an open classroom climate and student achievement, but this does not mean that applying all the practices more frequently is better. Some activities should be applied often in the classroom, while it might be best if others are practiced less.

\section{How to Understand Civic and Citizenship Education in Practice}

The contemporary concept of citizenship extends beyond understanding it as a legal status, beyond the link between the citizen and the state, and beyond the territory of a nation state both in the research literature and in educational and social policies (Huang \& Holmarsdottir, 2015). The contemporary notion of civic and citizenship education focuses on both civic education and citizenship education, as well as on their relationship with one's knowledge and understanding of formal institutions and the process of civic life (such as voting in elections), and one's knowledge and understanding of opportunities to participate and engage in both civic and civil society (Schulz et al., 2010). In addition, as cited by teachers and school principals from 38 participant countries of the ICCS 2009 study, the most important aims of civic and citizenship education include promoting one's knowledge of social, political, and civic institutions; citizens' rights and responsibilities; promoting students' critical and independent thinking; and developing students' skills and competencies in conflict resolution (Schulz et al., 2010: p. 15).

In 2005, European educational policies defined citizenship education as "school education for young people, which seeks to ensure that they become active and responsible citizens capable of contributing to the development and well-being of the society in which they live” (Eurydice, 2005: p. 10). In 2012, the European Commission specified that citizenship education would be carried out in school as "the aspects of education at the school level intended to prepare students to become active citizens, by ensuring that they have the necessary knowledge, skills and attitudes to contribute to the development and well-being of the society in which they live" (Eurydice, 2012: p. 8). However, there is a lack of consensus among scholars about what concrete role schools should play in educating democratic citizens (Fischman \& Haas, 2012). Among the different voices heard from different perspectives, Biesta (2011) argues that teaching citizenship should be distinguished from learning democracy. Education for democracy can be understood as education that prepares children for their future participation in democratic life by providing relevant knowledge, skills, and values. However, there are limits to what can be achieved when teaching about democracy. Biesta (2006) argues that this kind of education will not suffice in the promotion of democracy and democratic values. As such, there is an additional necessity for democratic forms of education, where students learn about democracy through participation in the democratic life itself. This is education through democracy, and it implies that there is an existence of democratic values that permeates all activities in school. Students cannot become democratic if schools do not practice democratic ideals (Biesta, 2006).

Meanwhile, Torney-Purta (2004) maintains that the civic and citizenship education policy and curriculum alone cannot guarantee the development of democratic values and attitudes among young people; rather, the presence of an open/democratic classroom climate can foster one's potential to develop civic values and virtues. A democratic classroom is characterized by a teacher that seeks to implement democratic and liberal values in teaching and learning activities (Ehman, 1980; Hahn, 1999; White, 1996). In this way, students are encouraged to express their own opinions, to take part in discussions, and engage in class matters. Previous research has repeatedly demonstrated the effective and significant role that teachers play in facilitating an interactive classroom. Teachers' classroom use of interactive discussions (Rubin, 2012; Torney-Purta \& Wilkenfeld, 2009), as well as discussions and debates pertaining to controversial issues in the classroom (Hess, 2009; Perliger et al., 2006) — in addition to students' experiences of what teachers do and what students do in an open climate classroom (Isac et al., 2014; Knowles \& McCafferty-Wright, 2015; Schulz et al., 2010)—are all positively associated with higher civic knowledge/skill achievement. 


\section{Data and Methods}

In this investigation, we used student data from Denmark, Norway, and Sweden, as obtained from the IEA's International Civic and Citizenship Education Study (ICCS) conducted in 38 countries in 2009. This was an international survey of students in their eighth year of school in most education systems, provided that the average age of students in this grade was 13.5 years or above at the time of the assessment. Both $8^{\text {th }}$ graders and $9^{\text {th }}$ graders from Norway participated in the ICCS 2009 study; here, we used the results of $9^{\text {th }}$ graders in our analysis, as Norwegian $8^{\text {th }}$ graders are one year younger than their Danish and Swedish peers in the same grade. The ICCS 2009 study assessed students' civic knowledge using a 79-item test, which includes four content domains: civic society and systems; civic principles; civic participation; and civic identities. One fourth of the test items contain factual knowledge of civics and citizenship, and the remaining $75 \%$ of items tested reasoning and analysis. The test items were grouped into seven clusters, and each student would complete one test booklet containing three of the seven clusters (Schulz et al., 2010).

Table 2 presents the number of cases, civic knowledge achievement, and student background variables used in our analysis. The ICCS 2009 data (accessible at the IEA study Website: http://www.iea.nl/iccs_2009.html) contain five plausible values created from students' test results during the ICCS 2009 (Brese et al., 2011); we use the first plausible value of student civic knowledge (PV1CIV) in our analysis. From the civic knowledge scores (PV1CIV), we extracted a group of students with high civic knowledge achievement, which is defined as a score at 601 and above (i.e., one standard deviation above the international mean at 500). Table 2 also presents the distribution of those "high achievers" among the three countries. While a total of $15 \%$ of students in the ICCS 2009 study had a civic knowledge achievement score that was one standard deviation above the mean, $41.5 \%$ of students from Denmark, 30.5\% of students from Norway, and $26.5 \%$ of students from Sweden were considered "high achievers".

The ICCS 2009 study also includes aspects of students' civic dispositions and attitudes among students, which are important when painting a nuanced picture of a group's potential democratic behaviour. Entering into such an in-depth and interesting discussion, however, is beyond the scope of this article, as we focus only on the effects of classroom practices on students' civic knowledge. Therefore, we limit our study to the knowledge component of the ICCS study.

For the measures associated with teaching practice, we used the question that measured students' perceptions of the classroom climate in the ICCS study (also referred to as the scale measuring the students' sense of "an open classroom climate"), which asked students to rate the frequency ("never", "rarely", "sometimes", and "often") with which each of seven events occurred during a regular class hour. These events included discussions of political and social issues and were classified as follow: 1) students are able to disagree openly with their teachers; 2) teachers encourage students to make up their own minds; 3) teachers encourage students to express their opinions; 4) students bring up current political events for discussion in class; 5) students express opinions in

Table 2. Student data from ICCS 2009 used for the analyses.

\begin{tabular}{lccc}
\hline & Denmark & Norway & Sweden \\
\hline Number of students N & 4508 & 2926 & 3464 \\
Average age, years (standard deviation) & $14.9(0.39)$ & $14.7(0.30)$ & $14.8(0.35)$ \\
$\begin{array}{l}\text { Average civic knowledge achievement PV1CIV } \\
\text { (standard deviation) }\end{array}$ & $575(98)$ & $541(103)$ & $536(100)$ \\
$\begin{array}{l}\text { Students with high civic knowledge achievement (i.e., a PV1CIV score at 601 and above, } \\
\text { one standard deviation away from the international average), \% }\end{array}$ & 41.5 & 30.5 & 26.5 \\
$\begin{array}{l}\text { Girls, \% } \\
\text { Parents' education attainments at the lower secondary level (ISCED 1, 2) \% }\end{array}$ & 52.1 & 49.9 & 50.1 \\
$\begin{array}{l}\text { Parents' education attainment at the upper secondary level (ISCED 3) \% } \\
\text { Parents' education attainment at the post-secondary level or short tertiary level } \\
\text { (ISCED 4, 5B), \% }\end{array}$ & 4.9 & 21.1 & 20.4 \\
Parents' education attainment at the tertiary level or higher (ISCED 5A or 6), \% & 51.4 & 24.5 & 20.8 \\
\hline
\end{tabular}

Note: All between-country differences are significant, $p<0.01$, except for average age and the average civic knowledge achievement (PV1CIV) between Norway and Sweden. 
class even when their opinions are different from most of the other students; 6) teachers encourage students to discuss the issue with people having different opinions; and 7) teachers present several sides of the issues when explaining them in class. Table 3 presents the descriptive statistics of the seven response items that measured an open/democratic classroom in the ICCS 2009 study.

Three aspects of the data analysis are reported: the descriptive analysis, correlation coefficients, and logistic regression. We first present, discuss, and compare the descriptive analysis of students' perceptions of their experiences in an open classroom across the three countries. The descriptive analysis shall provide a general picture of which classroom practices rarely or often occur among the three countries. Then, we look into each of the classroom practices and investigate its correlation with students' civic knowledge achievements across the three countries. We compare the strength of each of the classroom practices across in correlation with civic knowledge achievement among the three countries. Third, we apply logistic regression to estimate the effect of these classroom practices on the probabilities with which students become high achievers of civic knowledge. As there are four levels of application of the seven classroom practice items (i.e., never, seldom, sometimes, and often; see Table 3), a logistic regression analysis can estimate the effect of each level of application of each practice item using an odds ratio (OR). For example, an odds ratio can tell us how likely a student is to become a member of the group "high achievers" when a classroom practice (such as "the teacher encourages students to express their opinions") changes from "never" to "seldom" or from "never" to "often".

Our intention is not to try to explain the variation of civic knowledge achievement among the students between the three countries, nor is the intention to determine which factor outperforms the others in statistical terms. Rather, we want to highlight that how each classroom practice is implemented, as well as how and to what extent a combination of different classroom practices contribute to students' ability to achieve high civic knowledge in the three countries. Our analyses should provide some insightful and practical recommendations to encourage investment in successful democratic practices in the classroom for both teachers and teacher education programmes.

\subsection{Result 1: Similarities of Classroom Practices in the Three Countries}

As shown in Table 3, classroom practices among the three countries share some similarities. One similarity is that the option with the lowest frequency is "never" for each of the practices in all three countries, while

Table 3. Frequencies of responses on seven items measuring an open classroom climate (\%).

\begin{tabular}{|c|c|c|c|c|c|c|c|c|}
\hline & & $\begin{array}{l}\text { Students are able to } \\
\text { disagree openly } \\
\text { with their teachers }\end{array}$ & $\begin{array}{c}\text { Teachers } \\
\text { encourage } \\
\text { students to make } \\
\text { up their own } \\
\text { minds }\end{array}$ & $\begin{array}{l}\text { Teachers } \\
\text { encourage } \\
\text { students to } \\
\text { express their } \\
\text { opinions }\end{array}$ & $\begin{array}{l}\text { Students } \\
\text { bring up } \\
\text { current } \\
\text { political } \\
\text { events for } \\
\text { discussion in } \\
\text { class }\end{array}$ & $\begin{array}{l}\text { Students express } \\
\text { opinions in class } \\
\text { even when their } \\
\text { opinions are } \\
\text { different from } \\
\text { most of the other } \\
\text { students }\end{array}$ & $\begin{array}{c}\text { Teachers } \\
\text { encourage } \\
\text { students to } \\
\text { discuss the issue } \\
\text { with people } \\
\text { having different } \\
\text { opinions }\end{array}$ & $\begin{array}{l}\text { Teachers } \\
\text { present several } \\
\text { sides of the } \\
\text { issues when } \\
\text { explaining them } \\
\text { in class }\end{array}$ \\
\hline \multirow{4}{*}{ Denmark } & Never & 1.7 & 2.9 & 2.1 & 8.9 & 1.8 & 6.6 & 7.1 \\
\hline & Seldom & 6.9 & 9.7 & 5.6 & 32.8 & 11.5 & 23 & 22 \\
\hline & Sometimes & 39.6 & 34.1 & 25.8 & 41.8 & 38 & 43.7 & 41.2 \\
\hline & Often & 51.9 & 53.3 & 66.5 & 16.6 & 48.7 & 26.7 & 29.7 \\
\hline \multirow{4}{*}{ Norway } & Never & 3.3 & 4.6 & 4.9 & 9.9 & 4.9 & 10.3 & 6.2 \\
\hline & Seldom & 10.1 & 13.5 & 13.6 & 33.9 & 12.5 & 26.4 & 15.5 \\
\hline & Sometimes & 40 & 35.5 & 37 & 40.3 & 34.7 & 42.4 & 43.1 \\
\hline & Often & 46.6 & 46.3 & 44.4 & 15.9 & 47.8 & 21 & 35.2 \\
\hline \multirow{4}{*}{ Sweden } & Never & 3.5 & 4.3 & 3.7 & 12.4 & 4.5 & 10.4 & 9 \\
\hline & Seldom & 11.2 & 11.9 & 9.9 & 37.1 & 18.6 & 30.2 & 29.2 \\
\hline & Sometimes & 38.7 & 36.8 & 32.8 & 37 & 47 & 40.4 & 47.1 \\
\hline & Often & 46.7 & 47.1 & 53.6 & 13.5 & 29.9 & 19.1 & 14.7 \\
\hline
\end{tabular}

Note: All differences between countries are significant, $p<0.001$. 
"sometimes" and "often" are the options most frequently chosen for most classroom practice items across these countries. Figure 1 is a visual presentation of students' average reporting practices in a regular classroom on average. To understand the numbers, we refer to the response alternatives to each item of the question, as described earlier (i.e., 1 = "never", 2 = "rarely", 3 = "sometimes" and 4 = "often"), where a mean score close to the value of 4 indicates that a practice often occurs, while a mean score close to the value of 2 indicates that a practice seldom occurs. Following a rather similar pattern, in a regular classroom of Scandinavian schools, it was noted that students are often able to "openly disagree with teachers" and teachers encourage students to "make up their own minds" and "to express their opinion". Meanwhile, in a regular classroom in all three countries, students are seldom able to "bring up current political events for discussion". Moreover, students are only sometimes able to "express opinions in class even when their opinions are different from most of the other students", that teachers "encourage students to discuss the issue with people having different opinions", and teachers "present several sides of the issues when explaining them in class". However, most of the minor differences in students' experiences of an open classroom across the three countries are statistically significant.

\subsection{Result 2: The More the Better: Classroom Practices Are All Positive for Students' Civic Knowledge Achievement}

Table 4 presents the correlation coefficients of students' civic knowledge achievement in association with each of the practice items from a regular classroom in the three countries. First, all of the classroom practice items correlated positively with student civic knowledge achievement. For example if, in a regular classroom, students were "seldom" to "sometimes" or from "sometimes' to "often" when students are able to "disagree openly with their teachers" ( $r=0.261$ in Denmark, $r=0.279$ in Norway, $r=0.265$ in Sweden), Scandinavian students were able to achieve a 25-point increase, within a standard deviation, on their civic knowledge score. Second, in comparison with Denmark and Sweden, nearly all of the correlation coefficients related to the classroom practice items on achievement are stronger in Norway, except for the item "students bring up current political events

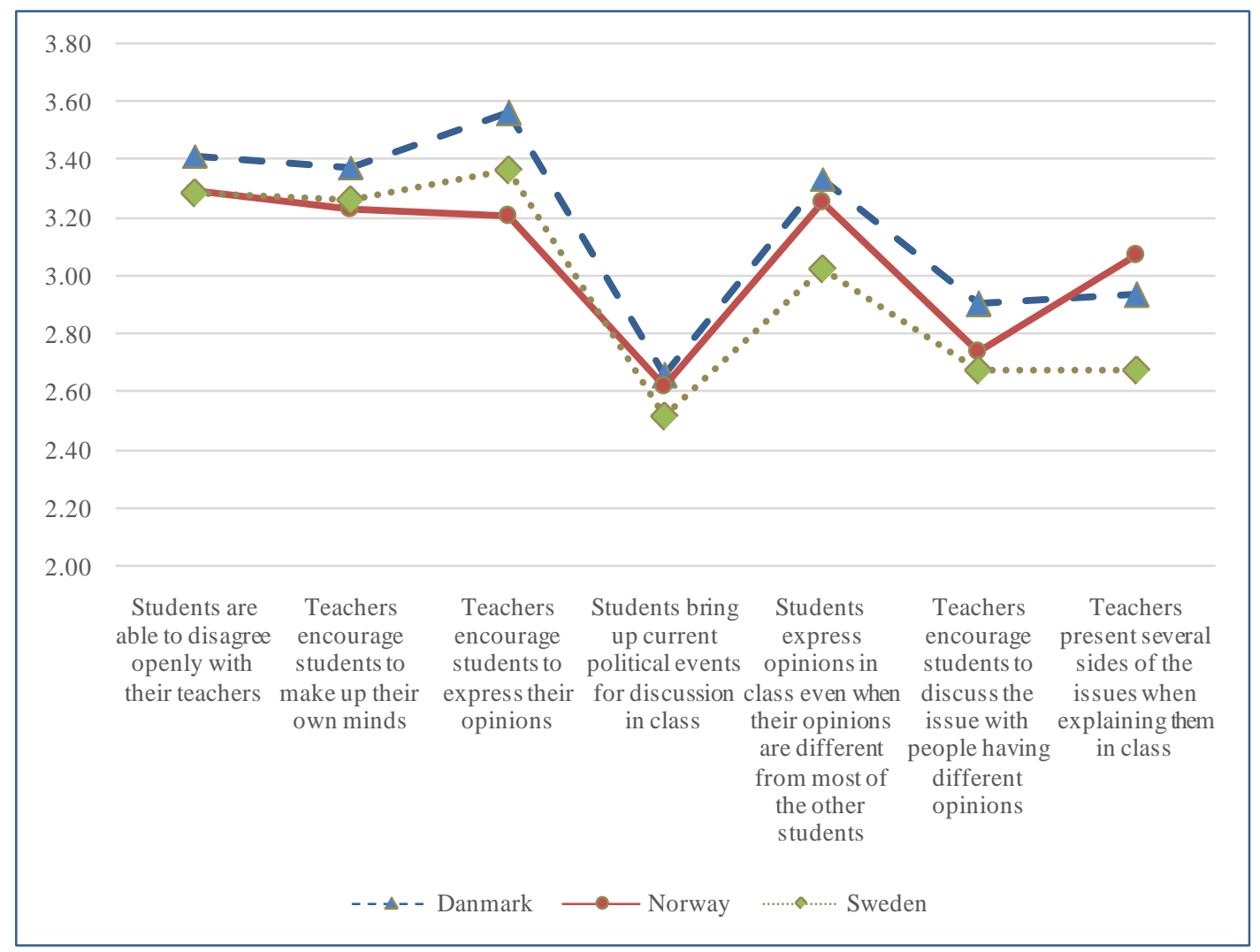

Figure 1. Students' average reporting patterns on the practices encountered in a regular classroom (means). 
Table 4. Correlation coefficients of classroom practices with student civic knowledge achievement (PV1CIV).

\begin{tabular}{|c|c|c|c|}
\hline & Denmark & Norway & Sweden \\
\hline Students are able to disagree openly with their teachers & 0.261 & 0.279 & 0.265 \\
\hline Teachers encourage students to make up their own minds & 0.293 & 0.329 & 0.268 \\
\hline Teachers encourage students to express their opinions & 0.205 & 0.286 & 0.245 \\
\hline Students bring up current political events for discussion in class & 0.145 & 0.114 & 0.108 \\
\hline $\begin{array}{l}\text { Students express opinions in class even when their opinions are different from most of the } \\
\text { other students }\end{array}$ & 0.068 & 0.310 & 0.188 \\
\hline Teachers encourage students to discuss the issue with people having different opinions & 0.110 & 0.166 & 0.144 \\
\hline Teachers present several sides of the issues when explaining them in class & 0.196 & 0.238 & 0.187 \\
\hline
\end{tabular}

Note: All coefficients are significant, $p<0.01$.

for discussion in class”. However, students' ability to take initiatives in the classroom (i.e., when a student brings up current political events for discussion in class) shows a weakly positive correlations with students' civic knowledge achievement in all three countries. Third, a contrast was found among the three countries when "students express opinions in class even when their opinions are different from most of the other students" (i.e., opinions against the mainstream), which correlates quite strongly with students' civic knowledge achievement in Norway, but very weakly with that in Denmark and Sweden.

Nevertheless, the relatively moderate correlation results in Table 4 do not necessarily imply that there is a straight linear relationship between the frequency with which students' experience each of the classroom practices and high achievement in civic knowledge. The results provide us with a rather vague message as to how the Scandinavian teachers implement these practices in their classrooms since we cannot conclude that the more often they apply these practices, the better it is for student achievement.

\subsection{Result 3: Some Practices Are More Important than Others for the Students with High Civic Knowledge Achievement}

Table 5 presents the logistic regression analysis using the frequency with which students encounter each classroom practice to predict their "membership" into the group of high achievement in terms of civic knowledge. The odds ratio (OR) tells us the extent to which each student is more or less likely to belongs to the "high achievers" group when a classroom practice changes from "never" to "rarely", or from "never" to "sometimes", or from "never" to "often". We use student gender and parental education attainment as the control variables. In Model 1, we include only the control variables, while we include the classroom practice variables in Model 2. We observe some changes in the effect of gender and levels of parental educational attainments from Model 1 to Model 2, indicating that classroom practices have moderating effects on the influence of gender and parental education on a student's ability to become a high achiever. In all three countries, inclusion of the classroom practice variables reduces some of the gender effect and the effects of parental education; this is especially true for the effects observed for parental education in Denmark and Norway. However, the increase in parental education levels consistently and significantly doubles and triples the chances with which Scandinavian students become high achievers.

A few teaching practices are significant in predicting a student's likelihood of becoming a "high achiever" in the three countries, although there are some similarities and differences. For instance, those students who experience often in a classroom where "students are able to disagree openly with their teachers" are over twice $(\mathrm{OR}=2.36)$ and three times $(\mathrm{OR}=2.97)$ more likely to be high achievers in Denmark and Sweden, respectively, than students who never experience this practice in the classroom. Second, students in classrooms where the teachers often "encourage students to make up their own minds" are two or three times more likely than those in classrooms where the teacher never does this to become a high achievers of civic knowledge in Denmark (OR = $2.41)$ and in Norway $(\mathrm{OR}=3.31)$, respectively.

In Denmark, the practice where "students bring up current political events for discussion in class" significantly increases the odds with which students achieve high civic knowledge by $53 \%$ (OR $=1.53$ ), although this same practice has no effect on students in Norway and Sweden. While the effect is not statistically significant 
Table 5. Logistic regression analysis of students’ experiences with classroom practices predicting high civic knowledge achievement in the three countries (OR).

\begin{tabular}{|c|c|c|c|c|c|c|}
\hline \multirow{2}{*}{ Control variables: background } & \multicolumn{3}{|c|}{ Model 1} & \multicolumn{3}{|c|}{ Model 2} \\
\hline & Denmark & Norway & Sweden & Denmark & Norway & Sweden \\
\hline \multicolumn{7}{|l|}{ Student gender (reference: “boy”) } \\
\hline Girl & $1.17^{*}$ & $1.42^{* * *}$ & $1.35^{* * *}$ & 1.08 & $1.20^{*}$ & 1.14 \\
\hline \multicolumn{7}{|l|}{$\begin{array}{l}\text { Parents' education attainments (reference: “lower secondary } \\
\text { level, ISCED 1, 2") }\end{array}$} \\
\hline Upper secondary level (ISCED 3) & $2.06^{* * *}$ & $3.01^{* *}$ & $2.94^{* * *}$ & $1.96^{* *}$ & $2.47^{*}$ & $3.10^{* *}$ \\
\hline Post-secondary level or short tertiary level (ISCED 4, 5B) & $4.22^{* * *}$ & $5.16^{* * *}$ & $5.79^{* * *}$ & $3.97^{* * *}$ & $3.91^{* *}$ & $5.96^{* * *}$ \\
\hline Tertiary level or higher (ISCED 5A or 6) & $7.92^{* * *}$ & $9.68^{* * *}$ & $8.46^{* * *}$ & $6.92^{* * *}$ & $7.43^{* * *}$ & $8.14^{* * *}$ \\
\hline
\end{tabular}

Independent variables: teaching practices

Students are able to disagree openly with their teachers (reference: “never”)

Rarely

$0.90 \quad 1.13 \quad 1.62$

Sometimes

Often

$1.31 \quad 1.22 \quad 1.75$

$2.36^{*} \quad 1.68 \quad 2.97^{* *}$

Teachers encourage students to make up their own minds (reference: “never”)

Rarely

Sometimes

Often

$1.35 \quad 2.06 \quad 1.12$

Teachers encourage students to express their opinions (reference: “never”)

Rarely

$1.95 \quad 0.74$

Sometimes

$1.32 \quad 1.96$

0.84

Often

Students bring up current political events for discussion in class (reference: “never”)

Rarely

Sometimes

$1.19 \quad 1.03 \quad 1.20$

Often

$1.53^{* *}$

0.00

1.26

Students express opinions in class even when their opinions are different from most of the other students (reference: “never”)

Rarely

Sometimes

$1.96 \quad 1.46 \quad 1.34$

Often

Teachers encourage students to discuss the issue with people having different opinions (reference:

Rarely

$\begin{array}{lll}0.87 & 0.98 & 0.80\end{array}$

Sometimes

$0.69^{*}$

0.73

$0.65^{*}$

Often

$0.66^{*}$

0.65

0.67

Teachers present several sides of the issues when explaining them in class (reference: “never”)

Rarely

Sometimes

$1.58^{* *} \quad 1.70$

1.07

Often

$1.80^{* * *}$

$1.91^{*}$

1.44

Variance explained (Nagelkerke $\mathrm{R}^{2}$ )

$8.3 \%$

$8.3 \% \quad 7.2 \%$

$19 \%$

$17.5 \%$

$15.5 \%$

Chi-square/df

$265.7 / 4$

$175.2 / 4 \quad 163.7 / 4$

$632.9 / 25$

$355.6 / 25$

$353.7 / 25$ 
for Danish and Swedish students, the classroom where "students [often] express opinions in class even when their opinions are different from most of the other students" increases students' odds of becoming high achievers in Norway by two and half times $(\mathrm{OR}=2.60)$ when compared to those in classrooms without this practice. Moreover, the classroom practice where "teachers [often] present several sides of the issues when explaining them in class" significantly increases the odds with which students attain high achievement in both Denmark $(\mathrm{OR}=1.80)$ and Norway $(\mathrm{OR}=1.91)$, while this practice is not statistically significant for high achievers in Sweden. Interestingly, the classroom practice where "teachers encourage students to discuss the issue with people having different opinions" appears to decrease students' odds of becoming high achievers in all three countries; this is significantly the case for students in Denmark and Sweden. It appears that students in classrooms where they "sometimes" (OR $=0.69)$ or "often" $(\mathrm{OR}=0.66)$ encounter this practice in Denmark, as well as those who "sometimes" encounter it in Sweden ( $\mathrm{OR}=0.65)$, have a $30 \%$ lower probability of becoming high achievers of civic knowledge.

The results presented in Table 5 illustrate the different patterns of classroom practices encountered during regular lessons among Scandinavian students who are high achievers in civic knowledge. Among Danish high achievers, it was found that often, these "students are able to disagree openly with their teachers" in their classrooms, "teachers encourage students to make up their own minds", "students bring up current political events for discussion", and "teachers present several sides of the issues when explaining them": however, never or rarely do "teachers encourage students to discuss the issues with people having different opinions". In the classrooms featuring Norwegian high achievers, it is often that "teachers encourage students to express their opinions", "students express their opinions even when their opinions are different from most of the other students", and "teachers present several sides of the issues when explaining them". In the classrooms with Swedish high achievers, it is often the case that "students are able to disagree openly with their teachers" and it is never or rarely that "teachers encourage students to discuss the issues with people having different opinions".

\section{Discussion}

An open or democratic classroom is probably the hardest practice to implement at a time when standardized testing places pressure on teachers to deliver a standardized curriculum instead of facilitating discussion and critical thinking. Inspired by previous research, the evidence shows that certain teaching practices encourage students' active engagement in the classroom; this is a key element that fosters student learning in civic knowledge (e.g., Hess, 2009; Rubin, 2012), as well as science, technology, engineering and mathematics (STEM) subjects (e.g., Lee \& Kinzie, 2012). Our results provide ample support for us to conclude that certain teaching practices facilitate student civic knowledge learning in the classroom when teachers encourage students to engage in discussions and when democratic values are implemented in teaching practices.

More importantly, our analyses provide a picture of the teaching practices employed in a classroom of Scandinavian high achievers in civic knowledge. All Scandinavian students experience rather similar classroom practices. For example, it is sometimes or often the case that "students are able to openly disagree with teachers", and "teachers encourage students to make up their own minds" and "to express their opinions"; less often, "students bring up current political events for discussion" (see Figure 1). All of these practices appear to be positively correlated with students' achievement in civic knowledge (see Table 4). However, for students with high achievement in civic knowledge, the positive effects of classroom practices become selective (see Table 5)—i.e., this positive effect is not found for all practices implemented in the classrooms that supposedly constitute "an open classroom climate", which supposedly should be the case that the more often these practices were used, the better for students' civic learning.

Certainly, our study can offer a "repeated" message to teachers in classrooms insofar as there are some instances where certain practices, when used more frequently ("the more the better"), enhance student civic learning. Such practices include those where teachers are open minded, where they present issues with several sides, and they encourage students to disagree, to make up their own minds, and to express their opinions. At the same time, instead of doing fewer of - or simply dismissing - those practices that have little effects or even negative effects on student achievement found in our analyses, we should ask questions and examine them more closely. For example, we should ask why the practices such as those that encourage students to take initiative (e.g., "students bring up current political issues for discussion in class") increase the chances with which Danish, but not Norwegian or Swedish, students will become high achievers. We should also ask why the practice where 
"teachers encourage students to discuss the issue with people having different opinions" does not yield a positive effect among high achieving students in all Scandinavian schools.

The novelty of our analysis lies in its approach to the scale of an "open classroom climate". In this study, individual students' perceptions of this classroom environment are determined by each teaching practice that is employed in this setting. We aimed to obtain insight into how each classroom practice is implemented, and how to what extent Scandinavian teachers combine these practices in their classrooms. Our results also carry implications for teacher education programmes in the three countries, particularly with respect to how well Scandinavian teachers-to-be are equipped with the necessary knowledge, competence, and skills to facilitate a truly democratic and open classroom climate, which includes initiatives made by both teachers and students. As a final point in this paper, we must admit that our study has its limitations insofar as it used ICCS 2009 data without 1) critiques on the definitions and concepts applied in assessing student learning in that study; and 2) following the intended data structure of the "open classroom climate" scale. In addition to inviting critiques and debates on the issues discussed in our study, we call for future research to be carried out in the Scandinavian schools to assess how practices where students are encouraged to take initiative are understood, conceived, and implemented by teachers in the classroom.

\section{References}

Barber, C., Sweetwood, S. O., \& King, M. (2015). Creating Classroom-Level Measures of Citizenship Education Climate. Learning Environments Research, 18, 197-216. http://dx.doi.org/10.1007/s10984-015-9180-7

Biesta, G. J. J. (2006). Beyond Learning: Democratic Education for a Human Future. Boulder, Colorado: Paradigm.

Biesta, G. J. J. (2011). Learning Democracy in School and Society: Education, Lifelong Learning, and the Politics of Citizenship. Rotterdam: Sense Publishers. http://dx.doi.org/10.1007/978-94-6091-512-3

Biseth, H. (2009). Democracy and Education in a Multicultural Scandinavia: What Mandate Is Designated to Educators? Intercultural Education, 20, 243-254. http://dx.doi.org/10.1080/14675980903138590

Biseth, H. (2012). Citizenship Education in Scandinavian Multicultural Schools: A Comparative Study of Students' and Teachers’ Perceptions. Citizenship Teaching and Learning, 7, 71-88. http://dx.doi.org/10.1386/ctl.7.1.71_1

Brese, F., Jung, M., Mirazchiyski, P., Schulz, W., \& Zuehlke, O. (2011). ICCS 2009 User Guide for the International Database. Amsterdam: International Association for the Evaluation of Educational Achievement (IEA).

Bruun, J. (2013). Denmark. In J. Ainley, W. Schulz, \& T. Friedman (Eds.), ICCS 2009 Encyclopedia: Approaches to Civic and Citizenship Education around the World (pp. 111-119). Amsterdam: International Association for the Evaluation of Educational Achievement (IEA).

Cicognani, E., Zani, B., Fournier, B., Gavray, C., \& Born, M. (2012). Gender Differences in Youths’ Political Engagement and Participation. The Role of Parents and of Adolescents' Social and Civic Participation. Journal of Adolescence, 35, 561-576. http://dx.doi.org/10.1016/j.adolescence.2011.10.002

Ehman, L. H. (1980). Change in High School Pupils Political Attitudes as a Function of Social Studies Classroom Climate. American Educational Research Journal, 17, 253-265. http://dx.doi.org/10.3102/00028312017002253

Eurydice (2005). Citizenship Education at School in Europe. Brussels: Eurydice.

Eurydice (2012). Citizenship Education in Europe. Brussels: Eurydice.

Fischman, G. E., \& Haas, E. (2012). Beyond Idealized Citizenship Education: Embodied Cognition, Metaphors, and Democracy. Review of Research in Education, 36, 169-196. http://dx.doi.org/10.3102/0091732X11420927

Hahn, C. (1999). Citizenship Education: An Empirical Study of Policy, Practices and Outcomes. Oxford Review of Education, 25, 231-250. http://dx.doi.org/10.1080/030549899104233

Hess, D. E. (2009). Controversy in the Classroom: The Democratic Power of Discussion. New York: Routledge.

Huang, L., \& Holmarsdottir, H. B. (2015). Youth at the Margins of Citizenship: A Review of European Youth Policy. In S. Bastien, \& H. B. Holmarsdottir (Eds.), Youth "At the Margins”: Critical Perspectives and Experiences of Engaging Youth in Research Worldwide (pp. 23-40). Rotterdam: Sense Publishers. http://dx.doi.org/10.1007/978-94-6300-052-9_2

Isac, M. M., Maslowski, R., Creemers, B., \& van der Werf, G. (2014). The Contribution of Schooling to Secondary-School Students’ Citizenship Outcomes across Countries. School Effectiveness and School Improvement, 25, 29-63. http://dx.doi.org/10.1080/09243453.2012.751035

Jacobsen, B., Troels Jensen, F., Madsen, M. B., Sylvestersen, M., \& Vincent, C. (2004). Den Vordende demokrat: En undersøgelse af skoleklassen som demokratisk lerested [The Future Democrat: An Examination of the Classroom as a Democratic Learning Environment]. Århus: Aarhus Universitetsforlag. 
Knowles, R. T., \& McCafferty-Wright, J. (2015). Connecting an Open Classroom Climate to Social Movement Citizenship: A Study of 8th Graders in Europe Using IEA ICCS Data. The Journal of Social Studies Research, 39, 255-269.

http://dx.doi.org/10.1016/j.jssr.2015.03.002

Lauglo, J., \& Øia, T. (2006). Education and Civic Engagement among Norwegian Youths (104 p). Oslo: Norwegian Social Research.

Levinson, M. (2010). The Civic Empowerment Gap. In L. R. Sherrod, J. Torney-Purta, \& C. A. Flanagan (Eds.), Handbook of Research on Civic Engagement in Youth (pp. 331-362). Hoboken, NJ: John Wiley \& Sons. http://dx.doi.org/10.1002/9780470767603.ch13

Lee, Y., \& Kinzie, M. (2012). Teacher Question and Student Response with Regard to Cognition and Language Use. Instructional Science, 40, 857-874. http://dx.doi.org/10.1007/s11251-011-9193-2

Lieberkind, J. (2015). Democratic Experience and the Democratic Challenge: A Historical and Comparative Citizenship Education Study of Scandinavian Schools. Scandinavian Journal of Educational Research, 59, 710-730. http://dx.doi.org/10.1080/00313831.2014.971862

Lind, F. (2013). Sweden. In J. Ainley, W. Schulz, \& T. Friedman (Eds.), ICCS 2009 Encyclopedia: Approaches to Civic and Citizenship Education around the World (pp. 373-387). Amsterdam: International Association for the Evaluation of Educational Achievement (IEA).

McIntosh, H., Hart, D., \& Youniss, J. (2007). The Influence of Family Political Discussion on Youth Civic Development: Which Parent Qualities Matter? Political Science \& Politics, 40, 495-499. http://dx.doi.org/10.1017/S1049096507070758

Mikkelsen, R., \& Fjeldstad, D. (2013). Norway. In J. Ainley, W. Schulz, \& T. Friedman (Eds.), ICCS 2009 Encyclopedia: Approaches to Civic and Citizenship Education around the World (pp. 313-321). Amsterdam: International Association for the Evaluation of Educational Achievement (IEA).

Mikkelsen, R., Fjeldstad, D., \& Lauglo, J. (2011). Morgendagens samfunnsborgere. Norske ungdomsskoleelevers prestasjoner og svar på spørsmål i den internasjonale demokratiundersøkelsen ICCS [Citizens of Tomorrow. Norwegian Youths’ Achievement and Responses to Questions in the International Survey on Democracy ICCS.] (Vol. 2/2011). Oslo: Acta Didactica.

OECD (2013). Education at a Glance 2013: OECD Indicators. Paris: OECD Publishing.

OECD (2015). Education Policy Outlook 2015: Making Reforms Happen. Paris: OECD Publishing.

Perliger, A., Canetti-Nisim, D., \& Pedahzur, A. (2006). Democratic Attitudes among High-School Pupils: The Role Played by Perceptions of Class Climates. School Effectiveness and School Improvement, 17, 119-140. http://dx.doi.org/10.1080/09243450500405217

Richardson, W. (2003). Connecting Political Discussion to Civic Engagement: The Role of Civic Knowledge, Efficacy and Context for Adolescents. PhD Thesis, College Park, MD: University of Maryland.

Rubin, B. C. (2012). Making Citizens: Transforming Civic Learning for Diverse Social Studies Classrooms. New York: Routledge.

Schulz, W., Ainley, J., Fraillon, J., Kerr, D., \& Losito, B. (2010). ICCS 2009 International Report: Civic Knowledge, Attitudes, and Engagement among Lower-Secondary School Students in 38 Countries. Amsterdam: International Association for the Evaluation of Educational Achievement (IEA).

Seider, S. (2012). The Influence of Parental Support upon the Community Service Learning Experiences of American College Students. Education, Citizenship, and Social Justice, 7, 271-288. http://dx.doi.org/10.1177/1746197912456340

Torney-Purta, J. (2004). Adolescents' Political Socialization in Changing Contexts: An International Study in the Spirit of Nevitt Sanford. Political Psychology, 25, 465-478. http://dx.doi.org/10.1111/j.1467-9221.2004.00380.x

Torney-Purta, J., \& Wilkenfeld, B. S. (2009). Paths to 21st Century Competencies through Civic Education Classrooms: An Analysis of Survey Results from Ninth-Graders (A Technical Assistance Bulletin). Chicago, IL: American Bar Association Division for Public Education.

White, P. (1996). Civic Virtues and Public Schooling: Educating Citizens for a Democratic Society. New York: Teachers College, Columbia University.

Zaff, J., Youniss, J., \& Gibson, C. (2009). An Inequitable Invitation to Citizenship: Non-College-Bound Youth and Civic Engagement. Washington DC: Philanthropy for Active Civic Engagement (PACE). 